\title{
Correlation Studied on Several Quantitative Traits in Induced Mutagenic Population of Grasspea (Lathyrus sativus L.)
}

\author{
Prabhat Kumar Singh ${ }^{1 *}$, R. Sadhukhan ${ }^{2}$ and Adyant Kumar ${ }^{3}$ \\ ${ }^{1}$ Department of Genetics and Plant Breeding, M. S. Swaminathan School of Agriculture, CUTM, \\ Paralekhmundhi, Odisha-761211, India \\ ${ }^{2}$ Department of Genetics and Plant Breeding, ${ }^{3}$ Department of Agronomy, Bidhan Chandra Krishi \\ Vishwavidyalaya, Mohanpur, Nadia, West Bengal-741252, India \\ *Corresponding author
}

\section{Keywords \\ Correlation, EMS, \\ Gamma rays, \\ Grasspea, Yield components.}

Article Info

Accepted:

07 September 2017

Available Online:

10 October 2017

\section{A B S T R A C T}

Seeds of three diverse genotypes of grasspea viz. Nirmal, Biol-212 and Berhampur Local treated with EMS $(0.5 \%$ and $1 \%)$, gamma rays $(400,500$ and $600 \mathrm{~Gy})$ and in combination (400Gy+0.5\% EMS and $400 \mathrm{~Gy}+1 \%$ EMS) were constituted as initial material for the present study. The experiment was conducted for 2012-15 winter seasons at District Seed Farm, BCKV, West Bengal, India. Correlation study was computed between yield and nine different yield components at different chemical concentration and radiation level in $\mathrm{M}_{2}$ and $\mathrm{M}_{3}$ generations. The correlation coefficient between seed yield per plant and its components were estimated at phenotypic level. The result revealed that all the characters showed significant and positive correlation with seed yield at different mutagenic treatment but not in all treatments however, 100 seed weight was positively correlated with seed yield at all mutagenic treatment in both generations (except 500 Gy treatment of Nirmal in $\mathrm{M}_{2}$ generation) professing that 100-seed weight was vital yield improving character in all three varieties of lathyrus under study. Henceforth, it can be suggested that selection of plant for different yield improving characters will be more effective in combination treatments in case of grasspea varieties under studied as maximum significant and positive relationship between yield and its components were noted in combination treatments.

\section{Introduction}

The genus Lathyrusis large with 187 species and sub-species being recognized (Allkin et al., 1983), out of which, four species viz. Lathyrussativus, Lathyrusodoratus, Lathyrusochyrous and Lathyrusaphaca are found in India. However, only Lathyrus sativus L. is the most commonly used for nutritional purposes, in the form of Seeds while, other species are cultivated to a lesser extent for both food and forage. The grasspea is endowed with many properties that combine to make it an attractive food crop in drought stricken, rain-fed areas where soil quality is poor and extreme environmental conditions prevail (Palmer et al., 1989, Ali M. Abd El-Moneim et al., 2000). Regardless of its tolerance to drought it has a very hardy and penetrating root system and therefore can be grown on a wide range of soil types, including very poor soil and heavy clays. 
Apart from the above mentioned incontestable advantages, grasspea is also characterized by a number of less favourable features, such as strong lodging, indeterminate growth habit, or excessively long period till ripeness, as well as the presence of anti-nutritional substances $(\beta$-ODAP) in seeds (Rybiñski and Pokora, 2002) which render the crop unsuitable for human consumption if present in higher amount (Mandal et al., 2015; Dixit et al., 2016; Sarker et al., 2017). Hence, one of the conditions for the introduction of the species to greater extent in Indian Agriculture is the genetic improvement of a number of unfavourable characteristics including yield. Since grasspea is self-pollinating crop and also exhibited inter specific incompatibility so its improvement through conventional breeding cannot be achieved exclusively. Induced mutagenesis thus seems to be an ideal methodology for the induction of desirable genetic variability and selection of several putative mutants.

Grain yield is the prime focus of any breeding programme including mutation breeding which is a complex and polygenic trait, highly influenced by many genetic factors and environmental fluctuations. Increase in yield is not the direct action of mutagen alone rather it also depends on other yield attributing interrelated characters hence direct selection for yield as such can be misleading. Therefore, knowledge of relationship between important yield traits and seed yield may help the researcher to identify suitable donors for a potential and successful breeding programme (Kumaresan and Nadrajan, 2002). In other words, character associations between yield components can be used as the best guide for successful yield improvement by indirect selection. The value of phenotypic and genotypic correlation provides the information about the relationship between the two or more than two independent variables. In plant breeding and genetics through correlation analysis of different traits can be valued. Knowledge with respect to association of various traits with seed yield would be of immense help in formulation of an effective and efficient selection and screening programme. Sufficient information regarding association among yield and yield components has already been reported in grasspea by various workers (Kumar and Dube, 2001; Parihar et al., 2013; Kamadi et al., 2015; Parihar et al., 2015 and Kour and Agarwal, 2016), but very few information is available in case of induced mutants of grasspea.

The objective of the present study was conceived to investigate whether physical radiation and chemical mutagen disturbed the normal relationship or not between different yield attributing characters during mutagenesis programme. The present study was undertaken to find out the association between yield and yield components in $\mathrm{M}_{2}$ and $\mathrm{M}_{3}$ generations in three grasspea varieties so that the derived information would be helpful in developing appropriate selection methods and improving the economically important characters.

\section{Materials and Methods}

The field experiment was conducted for 201215 winter seasons at District Seed Farm, Bidhan Chandra Krishi Viswavidyalaya, West Bengal, India. The experimental site comes under the Gangetic plains of West Bengal, India at latitude $22^{\circ} 58^{\prime} \mathrm{N}$ and longitude $88^{\circ} 32^{\prime}$ E with average altitude of $9.75 \mathrm{~m}$ above mean sea level (AMSL). BioL-212 is a somaclonal mutant of $\mathrm{P}-24$ having lower ODAP content $(<0.1 \%)$ but with longer duration and is poorly fitted in the cropping sequence of Coastal Bengal having short and mild winter. Nirmal variety, though adapted in grasspea growing areas for utera (relay) crop, was released long back in 1981 and has 
moderate ODAP content $(0.2 \%$ or higher). The later genotype, Berhampore Local, is locally adapted in some parts of Murshidabad district of West Bengal but has very high ODAP content $(>0.5 \%)$. Dry and healthy seeds of the three varieties were used to treated with physical (gamma ray) and chemical (EMS) mutagens.

The gamma radiation (400, 500 and $600 \mathrm{~Gy})$ was given to 300 seeds for each treatment at UGC- DAE consortium for scientific research, Kolkata centre (South campus of Jadavpur University, Salt Lake, Kolkata). The source of gamma rays was ${ }^{60} \mathrm{Co}$ and the dose rate was $7.12 \mathrm{~Gy} /$ minute. Similarly, same number of pre-soaked ( $9 \mathrm{~h}$, in distilled water) seeds was treated with $0.5 \%$ and $1 \%$ ethyl methane sulphonate (Sigma Chemical Company, USA) for $6 \mathrm{~h}$ at $\pm 25^{\circ} \mathrm{C}$. All solutions of the chemical mutagens were prepared in freshly prepared phosphate buffer having $\mathrm{pH}-7$. For combination treatments, 300 seeds each were first irradiated with 400 Gy of gamma rays and then followed by the two EMS concentrations $(0.5 \%$ and $1 \%)$. Subsequently the EMS treated seeds were thoroughly washed with running water for 1 hour before sowing to remove the residual effect of the chemical mutagen.

The treated seeds were sown immediately in the main field along with their respective controls in randomized block design (RBD) with three replications to raise the $M_{1}$ generation (2012-13). The $\mathrm{M}_{2}$ generation (2013-14) was raised from the composite sample of 25 seeds obtained from each $\mathrm{M}_{1}$ harvested plant of a treatment. In $\mathrm{M}_{2}$ generation observations were recorded for nine agronomic characters namely plant height $(\mathrm{cm})$, number of primary branches per plant, number of secondary branches per plans, number of pods per plant, number of seeds per pod, number of seeds per plant, 100-seed weight $(\mathrm{g})$, fresh weight per plant (g) and pod length $(\mathrm{cm})$. Based on yield and its component means ten plants were selected irrespective of treatments from each treatment. Seeds from selected $\mathrm{M}_{2}$ progeny of each treatment were bulked by taking an equal amount of seeds from all $\mathrm{M}_{2}$ plants and mixed thoroughly. A random sample of this bulk was sown to obtain $\mathrm{M}_{3}$ progeny during 2014-15. Observation for same agronomic character was taken during $\mathrm{M}_{3}$ generation also. Treatment wise association analysis of all varieties individually for different morphological characters with seed yield per plant was estimated in $\mathrm{M}_{2}$ and $\mathrm{M}_{3}$ generation. Phenotypic correlation among various character pairs were calculated by the formulae suggested by Khan and Khanum (1994).

\section{Results and Discussion}

The correlation coefficient between seed yield per plant and its components in $\mathrm{M}_{2}$ and $\mathrm{M}_{3}$ generation were estimated at phenotypic level for variety Nirmal (Table 1), Biol-212 (Table 2) and Berhampur Local level (Table 3). Interestingly, mutant population exhibited change of relationship in all correlated characters. In most of the mutagenic treatment of all varieties, the correlations coefficient was found to be higher than the control. Seed yield per plant in all the three varieties showed significant positive and negative association with nine characters studied at different radiation level and chemical mutagen treatment in both $\mathrm{M}_{1}$ and $\mathrm{M}_{2}$ generations. However, control population for most of the character showed non-significant positive correlation with seed yield per plant in all the three varieties.

Non-significant negative correlation was noted for secondary branches per plant in both generations, pod length in $\mathrm{M}_{3}$ generation in variety Nirmal; secondary branches per plant in both generation, plant height and primary branches per plant in $\mathrm{M}_{2}$ generation and pod length in $\mathrm{M}_{3}$ generation only in variety Biol- 
212 and pod per plant, fresh weight per plant and pod length in both generation, primary branches per plant in $\mathrm{M}_{3}$ generation and secondary branches per plant in $\mathrm{M}_{2}$ generation only in variety Berhampur Local.

The results revealed that, seed yield per plant for a character associated significantly in different ways in $\mathrm{M}_{2}$ and $\mathrm{M}_{3}$ generation in all three varieties. For a character, some mutagenic treatments showed positive association in one generation and negative association in another generation, some were associated positively in both generation while only treatment 400 Gy in variety Berhampur Local exhibited significant negative correlation between secondary branches per plant and seed yield per plant in both generation (Table 3). Primary branches per plant (600 Gy and 400 Gy+1\% EMS), secondary branches per plant (600 Gy and $400 \mathrm{~Gy}+0.5 \%$ EMS), number of seeds per pod (400 Gy+1\% EMS), number of seeds per plant (600 Gy and $400 \mathrm{~Gy}+1 \%$ EMS) and 100 seed weight $(0.5 \%$ EMS, 1\% EMS, 600 Gy and $400 \mathrm{~Gy}+0.5 \%$ EMS) exhibited significant positive association with seed yield per plant in variety Nirmal in $M_{2}$ and $M_{3}$ generation both (Table 1).

In variety Biol-212, plant height $(0.5 \%$ EMS and $400 \mathrm{~Gy}$ ), primary branches (1\% EMS), seed per pod (500 Gy and 400Gy+0.5\% EMS), seed per plant (400Gy+0.5\% EMS), fresh weight (400 Gy), 100 seed weight $(0.5 \%$ EMS and $400 \mathrm{~Gy})$ and pod length $(0.5 \%$ EMS) showed significant and positive correlation with seed yield per plant in both $\mathrm{M}_{2}$ and $\mathrm{M}_{3}$ generations (Table 2). However, in variety Berhampur Local plant height (400 Gy+1\% EMS), primary branches (1\% EMS and $600 \mathrm{~Gy}$ ), pods per plant (600 Gy), seeds per pod (400 Gy and $400 \mathrm{~Gy}+1 \%$ EMS), seeds per plant (600 Gy and $400 \mathrm{~Gy}+1 \%$ EMS), fresh weight (400 Gy+1\% EMS), 100 seed weight (600 Gy and $400 \mathrm{~Gy}+1 \%$ EMS) and pod length (400 Gy+1\% EMS) revealed significant positive association in both generation with seed yield per plant (Table 3 ). Selection at such treatment for respective character will be rewarding for improvement of seed yield. Apart from these fresh weights per plant with seed yield in 1\% EMS treatment showed significant negative correlation in $\mathrm{M}_{2}$ generation while it was positively correlated in $\mathrm{M}_{3}$ generation in variety Nirmal. In 500 Gyradiation dose of variety Biol-212, primary branches per plant exhibited negative and positive association with seed yield in $M_{2}$ and $M_{3}$ generation respectively whereas, in case of secondary branches per plant in $600 \mathrm{~Gy}$, the circumstance was reverse that is it was positively correlated in $\mathrm{M}_{2}$ generation and negatively correlated in $\mathrm{M}_{3}$ generation with seed yield. Hence selection for such characters at that treatment would not be effective for yield improvement.

Significant positive correlation of seed yield per plant with number of pods per plant in mutated population was also reported by Hassan et al., (2005) in chickpea. On the other hand, the characters like plant height, pods per plant, primary branches per plant, seeds per pod and 100-seed weight showed highly significant positive correlation with yield per plant in twent ysix induced genetic variant lines of blackgram reported by Baisakh et al., (2014). Senapati (2007) reported strong positive significant association of plant height, pods per plant, seeds per pod and 100-seed weight with yield at both phenotypic and genotypic levels in mutagenic population similar kind of significant positive association of different traits with yield were reported earlier by Vijayalakshmi et al., (2000) in chickpea, Venkatesan et al., (2004), Veeramani et al., (2005) and Isha Praveen et al., (2011) in blackgram in normal population. 
Table.1 Correlation between seed yield and its components in $\mathrm{M}_{2}$ and $\mathrm{M}_{3}$ generation for variety Nirmal

\begin{tabular}{|c|c|c|c|c|c|c|c|c|c|c|c|c|c|c|c|c|c|c|}
\hline \multirow{2}{*}{ Treatment } & \multicolumn{2}{|c|}{ Plant height } & \multicolumn{2}{|c|}{ Primary branches } & \multicolumn{2}{|c|}{ Secondary branches } & \multicolumn{2}{|c|}{ Pods per plant } & \multicolumn{2}{|c|}{ Seeds per pod } & \multicolumn{2}{|c|}{ Seeds per plant } & \multicolumn{2}{|c|}{ Fresh weight } & \multicolumn{2}{|c|}{100 seed weight } & \multicolumn{2}{|c|}{ Pod length } \\
\hline & $\mathbf{M}_{2}$ & $\mathbf{M}_{3}$ & $\mathbf{M}_{2}$ & $\mathbf{M}_{3}$ & $\mathbf{M}_{2}$ & $\mathbf{M}_{3}$ & $\mathbf{M}_{2}$ & $\mathbf{M}_{3}$ & $\mathbf{M}_{2}$ & $\mathbf{M}_{3}$ & $\mathbf{M}_{2}$ & $\mathbf{M}_{3}$ & $\mathbf{M}_{2}$ & $\mathbf{M}_{3}$ & $\mathbf{M}_{2}$ & $\mathbf{M}_{3}$ & $\mathbf{M}_{2}$ & $\mathbf{M}_{3}$ \\
\hline Control & 0.229 & 0.079 & 0.243 & 0.207 & -0.378 & -0.108 & 0.232 & 0.193 & 0.097 & 0.193 & 0.109 & 0.100 & 0.273 & 0.311 & 0.271 & 0.189 & 0.069 & -0.227 \\
\hline $0.5 \%$ EMS & 0.052 & 0.234 & 0.288 & 0.311 & 0.018 & 0.258 & $0.424 *$ & -0.170 & 0.133 & -0.363 & 0.285 & 0.375 & 0.133 & $0.400 *$ & $0.465^{*}$ & $0.441^{*}$ & $-0.613 * *$ & -0.309 \\
\hline $1 \%$ EMS & 0.009 & $0.473^{*}$ & -0.316 & $0.436^{*}$ & 0.259 & $0.433^{*}$ & 0.074 & -0.008 & -0.372 & $0.580^{* *}$ & 0.203 & $0.675^{* *}$ & $-0.542 * *$ & $0.437 *$ & $0.440 *$ & $0.729 * *$ & -0.332 & $0.508 * *$ \\
\hline $400 \mathrm{~Gy}$ & 0.228 & -0.324 & $0.429 *$ & 0.086 & $-0.491 *$ & -0.135 & -0.182 & $0.398^{*}$ & $-0.633 * *$ & 0.153 & 0.169 & 0.291 & $0.474 *$ & -0.237 & $0.628 * *$ & 0.194 & 0.300 & $-0.403 *$ \\
\hline 500Gy & $-0.418^{*}$ & -0.053 & 0.139 & 0.108 & -0.278 & -0.173 & 0.320 & 0.287 & 0.127 & 0.371 & $0.399 *$ & -0.208 & 0.219 & 0.206 & $-0.409^{*}$ & -0.159 & 0.132 & 0.295 \\
\hline $600 \mathrm{~Gy}$ & -0.232 & $-0.544 * *$ & $0.632 * *$ & $0.399^{*}$ & $0.463^{*}$ & $0.569 * *$ & $0.446^{*}$ & -2.970 & $0.716^{* *}$ & 0.239 & $0.684 * *$ & $0.457 *$ & -0.142 & 0.088 & $0.708 * *$ & $0.692 * *$ & -0.150 & -0.174 \\
\hline $400 \mathrm{~Gy}+$ & $-0.536 * *$ & 0.093 & $0.498 *$ & -0.119 & $0.648^{* *}$ & $0.429 *$ & $0.400^{*}$ & 0.146 & -0.379 & $0.431 *$ & -0.260 & 0.0 & -0.098 & 0.294 & $0.527 * *$ & $0.493^{*}$ & $-0.518 * *$ & -0.191 \\
\hline $400 \mathrm{~Gy}+1 \% \mathrm{EMS}$ & 0.227 & 0.382 & $0.552 * *$ & $0.557 * *$ & 0.236 & 0.307 & -0.242 & $0.483^{*}$ & $0.584 * *$ & $0.455^{*}$ & $0.718 * *$ & $0.715 * *$ & 0.388 & $0.529 * *$ & -0.208 & 0.389 & 0.088 & $0.397 *$ \\
\hline
\end{tabular}

* Significant at $5 \%$ level, ** Significant at $1 \%$ level.

Table.2 Correlation between seed yield and its components in $\mathrm{M}_{2}$ and $\mathrm{M}_{3}$ generation for variety Biol-212

\begin{tabular}{|c|c|c|c|c|c|c|c|c|c|c|c|c|c|c|c|c|c|c|}
\hline \multirow{2}{*}{ Treatment } & \multicolumn{2}{|c|}{ Plant height } & \multicolumn{2}{|c|}{ Primary branches } & \multicolumn{2}{|c|}{ Secondary branches } & \multicolumn{2}{|c|}{ Pods per plant } & \multicolumn{2}{|c|}{ Seeds per pod } & \multicolumn{2}{|c|}{ Seeds per plant } & \multicolumn{2}{|c|}{ Fresh weight } & \multicolumn{2}{|c|}{100 seed weight } & \multicolumn{2}{|c|}{ Pod length } \\
\hline & $\mathbf{M}_{2}$ & $\mathbf{M}_{3}$ & $\mathbf{M}_{2}$ & $\mathbf{M}_{3}$ & $\mathbf{M}_{2}$ & $\mathbf{M}_{3}$ & $\mathbf{M}_{2}$ & $\mathbf{M}_{3}$ & $\mathbf{M}_{2}$ & $\mathbf{M}_{3}$ & $\mathbf{M}_{2}$ & $\mathbf{M}_{3}$ & $\mathbf{M}_{2}$ & $\mathbf{M}_{3}$ & $\mathbf{M}_{2}$ & $\mathbf{M}_{3}$ & $\mathbf{M}_{2}$ & $\mathbf{M}_{3}$ \\
\hline $\mathrm{rol}$ & -0.125 & 0.269 & -0.155 & 0.128 & 0.197 & -0.270 & 0.231 & 0.209 & 0085 & 0.266 & 0.182 & 0.161 & 0.063 & 0.166 & 0.165 & 0.194 & 0.163 & -0.108 \\
\hline $0.5 \%$ EMS & $1 *$ & $0.449^{*}$ & & & & & & & 0.285 & $0.444 *$ & $0.447^{*}$ & & -0.278 & & $0.738 * *$ & $0.591 * *$ & $0.462 *$ & $0.466^{*}$ \\
\hline $1 \%$ EMS & & & & & & & & & & & & & & & & & & 0.272 \\
\hline & & & & & & & & & & & & & & & & & & $-0.435^{*}$ \\
\hline $500 \mathrm{~Gy}$ & $-(-1$ & 86 & $.414 *$ & F & $466^{*}$ & & 0.182 & & 0.40 & & 0.199 & 0.2 & -0.079 & $0.433 *$ & 0.363 & 0.6 & 0.094 & 0.358 \\
\hline 600 Gy & & -0.261 & 0.249 & 0.079 & $0.711^{* *}$ & $-0.426^{*}$ & 0.284 & -0.116 & $0.537 * *$ & 0 . & $0.488^{*}$ & -0.234 & $0.420 *$ & -0.340 & $0.675^{* *}$ & -0.137 & $-0.537 * *$ & 0.065 \\
\hline $400 \mathrm{~Gy}+$ & -0.195 & & & & & & $0.733 * *$ & & $0.749 * *$ & $0.491 *$ & & & -0.138 & $-0.410^{*}$ & 0.281 & 0.343 & 0.315 & $-0.398 *$ \\
\hline $400 \mathrm{~Gy}+1 \% \mathrm{EMS}$ & -0.086 & -0.148 & $616^{* *}$ & -0.319 & $.447 *$ & 0.205 & $0.492 *$ & 0.304 & -0.164 & -0.365 & $0.509 * *$ & -0.245 & 0.101 & 0.100 & -0.076 & $0.491 *$ & $0.491 *$ & 0.395 \\
\hline
\end{tabular}

* Significant at $5 \%$ level, ** Significant at $1 \%$ level.

Table.3 Correlation between seed yield and its components in $\mathrm{M}_{2}$ and $\mathrm{M}_{3}$ generation for variety Berhampur Local

\begin{tabular}{|c|c|c|c|c|c|c|c|c|c|c|c|c|c|c|c|c|c|c|}
\hline \multirow[t]{2}{*}{ Treatment } & \multicolumn{2}{|c|}{ Plant height } & \multicolumn{2}{|c|}{ Primary branches } & \multicolumn{2}{|c|}{$\begin{array}{c}\text { Secondary } \\
\text { branches }\end{array}$} & \multicolumn{2}{|c|}{ Pods per plant } & \multicolumn{2}{|c|}{ Seeds per pod } & \multicolumn{2}{|c|}{ Seeds per plant } & \multicolumn{2}{|c|}{ Fresh weight } & \multicolumn{2}{|c|}{100 seed weight } & \multicolumn{2}{|c|}{ Pod length } \\
\hline & $\mathbf{M}_{2}$ & $\mathbf{M}_{3}$ & $\mathbf{M}_{2}$ & $\mathbf{M}_{3}$ & $\mathbf{M}_{2}$ & $\mathbf{M}_{3}$ & $\mathbf{M}_{2}$ & $\mathbf{M}_{3}$ & $\mathbf{M}_{2}$ & $\mathbf{M}_{3}$ & $\mathbf{M}_{2}$ & $\mathbf{M}_{3}$ & $\mathbf{M}_{2}$ & $\mathbf{M}_{3}$ & $\mathbf{M}_{2}$ & $\mathbf{M}_{3}$ & $\mathbf{M}_{2}$ & $\mathbf{M}_{3}$ \\
\hline Control & 0.092 & 0.282 & 0.159 & -0.137 & -0.204 & 0.197 & -0.131 & -0.014 & 0.289 & 0.187 & 0.153 & 0.122 & -0.334 & -0.190 & 0.137 & 0.329 & -0.329 & -0.306 \\
\hline $0.5 \%$ EMS & -0.202 & $0.437 *$ & -0.197 & -0.167 & 0.093 & -0.224 & 0.169 & 0.230 & -0.094 & -0.255 & 0.119 & -0.095 & 0.088 & -0.128 & $0.461 *$ & 0.388 & -0.156 & -0.164 \\
\hline $1 \%$ EMS & -0.374 & -0.203 & $0.774 * *$ & $0.398^{*}$ & 0.090 & $0.404 *$ & 0.083 & -0.175 & -0.221 & 0.251 & -0.142 & -0.148 & 0.208 & 0.094 & 0.377 & $0.428^{*}$ & 0.249 & 0.227 \\
\hline $400 \mathrm{~Gy}$ & $-0.413 *$ & -0.293 & 0.114 & 0.090 & $-0.551 * *$ & $-0.461 *$ & $0.404 *$ & $-0.403^{*}$ & $0.441^{*}$ & $0.466^{*}$ & 0.201 & 0.277 & $0.441 *$ & $-0.399 *$ & -0.286 & $0.404 *$ & -0.333 & 0.294 \\
\hline $500 \mathrm{~Gy}$ & 0.212 & 0.366 & $-0.443 *$ & 0.307 & 0.148 & $0.439 *$ & -0.158 & 0.243 & 0.296 & 0.191 & 0.209 & $0.599 * *$ & -0.118 & 0.368 & 0.228 & $0.558 * *$ & 0.306 & 0.321 \\
\hline 600 Gy & $-0.714 * *$ & $0.409 *$ & $0.531 * *$ & $0.658 * *$ & $0.633 * *$ & 0.215 & $0.511 * *$ & $0.582 * *$ & $-0.482 *$ & $0.633 * *$ & $0.529 * *$ & $0.708^{* *}$ & 0.377 & 0.341 & $0.711^{* *}$ & $0.688^{* *} *$ & 0.156 & $-0.417 *$ \\
\hline $\begin{array}{l}400 \\
\text { Gy+0.5\%EMS }\end{array}$ & -0.177 & -0.089 & 0.319 & 0.255 & $0.426^{*}$ & 0.193 & -0.094 & 0.359 & -0.384 & $-0.446^{*}$ & 0.338 & -0.203 & -0.306 & 0.257 & 0.055 & -0.386 & $-0.413^{*}$ & -0.284 \\
\hline $\begin{array}{l}400 \\
\text { Gy+1\%EMS }\end{array}$ & $0.406^{*}$ & $0.722 * *$ & -0.287 & $0.481 *$ & -0.241 & -0.377 & 0.261 & $0.472 *$ & $0.559 * *$ & $0.409^{*}$ & $0.641 * *$ & $0.500^{*}$ & $0.568 * *$ & $0.553 * *$ & $0.566^{* *}$ & $0.502 *$ & $0.493 *$ & $0.477 *$ \\
\hline
\end{tabular}

* Significant at $5 \%$ level, ** Significant at $1 \%$ level. 
However, Ahmad et al., (2012) reported that plant height at maturity, cluster per plant and number of pods per plant had negative significant phenotypic correlation with seed yield per plant whereas number of branches per plant showed negative and insignificant phenotypic correlation with seed yield per plant in gamma rays irradiated population of mungbean. Among the correlated characters,seed yield per plant showed highest magnitude of positive correlation coefficient with100 seed weight (0.729) at 1\% EMS treatment in variety Nirmal, number of seeds per plant $(0.793)$ at $400 \mathrm{~Gy}+0.5 \%$ EMS in Biol-212 and number of primary branches per plant (0.774) at 1\% EMS treatment in Berhampur Local agreeing that these characters at that particular treatment was most important yield contributing character in both normal and mutant populations of respective genotypes (Tables 1, 2 and 3). Similar significant positive correlation of yield per plant with number of pods per plant and fertile branches and 100 seed weight with yield per plant in mutagenic population were reported by Khan et al., (2004) in greengram. Fascinatingly, 100 seed weight was positively correlated with seed yield per plant at all mutagenic treatment in both generations (except 500 Gy treatment of Nirmal in $\mathrm{M}_{2}$ generation) professing that 100-seed weight was vital yield attributing character irrespective of mutagenic treatments in all three varieties of lathyrus under study. The result agrees with Amaranath et al., (1990) and Singh and Singh (1999) reported positive correlation of 100-seed weight with total plant yield in soybean.

Combining all, affirmed plant height, fresh weight per plant and pod length were mostly associated negatively with yield per plant hence number of primary and secondary branches per plant, number of pods per plant, number of seeds per pod, number of seeds per plant, and 100 seed weight were found to be important yield contributing characters consistently in all mutant population. The results, consequently, inferred that 100 -seed weight would like to produce significant correlated positive response to yield in all mutant population. Plant breeder always seeks minimum number of characters during selection procedure, which are effective in improving yield. Therefore, 100-seed weight should be considered as most important selection criteria for yield improvement in Lathyrus. Selection for plant having bold seed would obviously result in plant types with more seed yield. Along with pods per plant, number of branches per plant, number of seeds per podand number of seeds per plant was observed to be important yield components in the mutagen treated population. Though fresh weight per plant was mostly associated negatively with seed yield hence selection of plant with high fresh weight might be used for fodder purpose. Thus, restructuring or selection of plants with bold seed, more number of pods per plant, number of branches per plant, number of seeds per pod and number of seeds per plant would likely to aid in evolving varieties with high seed yield on the other hand selection of plant with high fresh weight resulting in development of high fodder yielding verities. Irrespective of different mutagenic treatments, maximum significant and strong positive association between different yield attributing character and yield per plant were noted in combination treatments. Hereafter, it can be suggested that selection of plant for different yield improving characters will be more effective in combination treatments of physical and chemical mutagens in case of Lathyrus varieties under studied.

\section{Acknowledgement}

The authors gratefully acknowledge the help rendering by Dr. Avijit Saha, Senior Scientist, UGC- DAE Consortium for Scientific 
Research, Kolkata Centre for his kind help in irradiating the experimental materials with great care. Authors are also very thankful to Prof (Dr.) H. K. Sarkar, former Prof. and H.O.D., Dept. of Genetics and Plant Breeding, B.C.K.V., West Bengal for their timely valuable suggestion during the study.

\section{References}

Ahmad, H.M., Ahsan, M., Ali, Q. and Javed, I., 2012. Genetic variability, heritability and correlation studies of various quantitative traits of mung bean (Vigna radiate $\mathrm{L}$.) at different radiation levels. International Research Journal of Microbiology. 3(11), 352-362.

Ali, M., Abd El-Moneim, Dorrestein M., and Mulugeta, W., 2000. Improving the nutritional quality and yield potential ofgrasspea (Lathyrus sativus L.). Food Nutri. Bulletin. 21(4), 493-496.

Allkin, R., Macfarlance, T. D., White, R. J., Bisby, F. A., and Adey, M. E., 1983. Names and synonyms of species and subspecies in the Vicieae. Vicieae Database Project.Issue 2, Southampton.

Amaranath, K.C.N., Viswanatha, S.R. and Chennakeshahva, S.R., 1990. Phenotypic and genotypic correlation coefficient of some quantitative characters in soybean (Glycine max L. Merrill). Mysore J. Agric. Sci.24, 445449.

Baisakh, B., Das, T.R. and Panigrahi, K.K., 2014. Genetic variability and correlation analysis for yield and yield contributing traits in advanced mutant lines of black gram. Journal of Food Legumes. 27 (3), 202-205.

Dixit, G.P., Parihar, A. K., Bohra, A., and Singh, N. P., 2016. Achievements and prospects of grass pea (Lathyrus sativus L.) improvement for sustainable food production. Science direct. The Crop Journal. 4, 407-416.
Hassan, M., Atta, B.M., Shah, T.M., Haque, M.A., Syed, H., and Alam, S., 2005. Correlation and path coefficient studies in induced mutants of chickpea (Cicer arietinum L.). Pak. J. Bot. 37, 293-298.

Isha, P.S., Reddi, S.M., Reddy, D.M. and Sudhakar, P., 2011. Correlation and path coefficient analysis for yield and yield components in black gram (Vigna mungo (L.) Hepper). International Journal of Applied Biology and Pharmaceutical Technology. 2, 619625.

Kamadi, S.R., Bhasme, S.P., Neharkar, P.S., Bhagat, G.J., Karhale, S.S., and Kadu, P.R., 2015. Genetic variability and correlation studies in local collections of grasspea (Lathyrus sativus L.). International Journal of Tropical Agriculture. 33(2), 1441-1444.

Khan, I.A., and Khanum, A., 1994. Fundamentals of Biostatistics. Ukaaz Publishers, Hyderabad, India.

Khan, S., Wani, M.R. and Kumar, P., 2004. Induced genetic variability for quantitative traits in Vigna radiata (L.) Wilczek. Pak. J. Bot.36, 845-850.

Kour, J., and Agarwal, N., 2016. Correlation and Path Coefficient Analysis of Yield Components in Advanced Lines of Grasspea (Lathyrus sativus L.). International Journal of Bio-Resource \& Stress Management. 7, 682-686.

Kumar, S., and Dubey, D.K., 2001. Variability, heritability and correlation studies in grasspea (Lathyrus sativus L.). Lathyrus Lathyrism Newsletter. 2, 79-81.

Kumaresan, D., and Nadrajan, N., 2002. Association of yield with some biometrical and physiology characters over different environments in sesame (Sesamum indicum L.). Sesame and Safflower Newsletter. 17, 13-16.

Mandal, R., Sadhukhan, R., Mandal, N., Tarafdar, J. and Sarkar, A., 2015. 
Assessment of genetic diversity and trait association in grass pea using morphometric, grain protein and seed ODAP content. Range Mgmt. \& Agroforestry. 36 (2), 136-140.

Palmer, V.S., Kaul, A.K., and Spencer, P.S., 1989. International Network for the Improvement of Lathyrussativus and the Eradication of Lathyrism (INILSEL): A TWMRF initiative. in The Grasspea: Threat and Promise Proc. of the International Network for the Improvement of Lathyrus sativus and the Eradication of Lathyrism (P. Spencer, ed.). Third World Medical Research Foundation, New York.pp. 219-223.

Parihar, A.K., Dixit, G.P. and Singh, D., 2013. Multivariate analysis of various agronomic traits in grasspea (Lathyrus spp) germplasm. Indian Journal of Agricultural Sciences. 83 (5), 570-575.

Parihar, A.K., Dixit, G.P. and Singh, D., 2015. Genetic variability analysis for quantitative traits in a germplasm set of grasspea (Lathyrus spp.). Legume Research. 38 (4), 461-464.

Rybiñski, W., and Pokora, L., 2002. The influence of helium-neon laser and chemomutagen (MNU) on variability of traits in $\mathrm{M}_{1}$ progeny of grasspea (Lathyrus sativus $\quad$ L.). Acta
Agrophysica, 62, 127-134.

Sarkar, A., Fikre, A., Ali M Abd El-Moneim, Nakkoula, H. and Singh, M., 2017. Reducing anti-nutritional factor and enhancing yield with advancing time of planting and zinc application in grasspea in Ethiopia. J Sci Food Agric. doi:10.1002/jsfa.8433.

Senapati, N., 2007. Induction of mutations and their scope on improvement of productivity in black gram ( $V$. mungo L. Hepper). Ph.D. Thesis, OUAT, Bhubaneswar.

Singh, J., and Singh, B., 1999. Genetic variability and correlation studies in soybean (Glycine max L. Merrill). J. Oil Seeds Res.16, 118-120.

Veeramani, V.N.M., Thangavel, P. and Ganesan, J., 2005. Genetic variability, heritability and genetic advance analysis in segregating generation of blackgram. Legume Research. 28, 49-51.

Venkatesan, M., Veeramani, N., Anbuselvam, Y. and Ganesan, J., 2004. Correlation and path analysis in black gram. Legume Research. 27, 197-200.

Vijayalakshmi, N.V.S., Jagdish, K., and Rao, T.N., 2000. Variability and correlation studies in Desi, Kabuli and intermediate chickpeas. Legume Research. 23, 232236.

\section{How to cite this article:}

Prabhat Kumar Singh, R. Sadhukhan and Adyant Kumar. 2017. Correlation Studied on Several Quantitative Traits in Induced Mutagenic Population of Grasspea (Lathyrus sativus L.). Int.J.Curr.Microbiol.App.Sci. 6(10): 612-619. doi: https://doi.org/10.20546/ijcmas.2017.610.075 